International Research Journal of Management, IT \& Social Sciences
Available online at https://sloap.org/journals/index.php/irjmis/
Vol. 7 No. 3, May 2020, pages: 11-21
ISSN: 2395-7492
https://doi.org/10.21744/irjmis.v7n3.881

\title{
The Effect of Experiential Marketing, Social Media Marketing, and Brand Trust on Repurchase Intention in Ovo Applications
}

Article history:

Submitted: 18 January 2020

Revised: 09 February 2020

Accepted: 27 March 2020

\section{Keywords:}

brand trust;

experiential marketing;

Ovo applications;

repurchase intention;

social media marketing;

\begin{abstract}
This research was conducted to determine the effect of experiential marketing, social media marketing, and brand trust partially on repurchase intention. This research was conducted on OVO application users in Denpasar City. This study uses a quantitative approach. Respondents have taken as many as 160 respondents with a Non-probability sampling technique with the purposive sampling method. In research data obtained through the distribution of questionnaires. The testing method used in this study is the Linear Regression Test. The results in this study are experiential marketing, social media marketing, and brand trust partially positive and significant effect on repurchase intention.
\end{abstract}

International research journal of management, IT and social sciences (C) 2020. This is an open access article under the CC BY-NC-ND license (https://creativecommons.org/licenses/by-nc-nd/4.0/).

Corresponding author:

Nyoman Sri Subawa,

Faculty of Economic and Business, Universitas Pendidikan Nasional

J1. Bedugul No. 39, Denpasar, Bali, Indonesia.

Email address: shribawa@undiknas.ac.id

\footnotetext{
aniversitas Pendidikan Nasional, Indonesia

b Universitas Pendidikan Nasional, Indonesia

Universitas Pendidikan Nasional, Indonesia
} 


\section{Introduction}

The development of increasingly advanced technology that currently has an impact on the use of digital technology. Activities carried out digitally based or using technology. This change in behavior can be observed in daily activities, one of which is in the payment system. Non-cash payment system has been widely used.

In a survey conducted by Pricewaterhouse-Coopers (PwC), (2019), it was stated that Indonesians have experienced an increase in online transactions that use mobile payments. With the increasing use of mobile applications, mobile payment is also increasingly rapid (Nugroho et al., 2017). With this phenomenon, many companies have brought up mobile payment systems in Indonesia. Like PT. Visionet Internasional (OVO), is one of the applications and financial services in Indonesia. The collaboration between OVO and Grab and Tokopedia makes OVO a digital shipping platform in Indonesia that can be accepted in retail networks, food stalls, shops, e-commerce, to online services with more than 500,000 offline outlets. This shows that developing business models tend to adopt and emulate the mobile banking business model in general. Mobile payment needs to be developed so that there are innovations, and fill existing opportunities (Mawarrini, 2017).

Receiving payments via cellular depends on the ability of service providers to build a network of partners and customers, simultaneously (Nejad et al., 2016). Payment service providers through cellular and business partners must be made so that all efforts can improve the consumer experience (Dinh et al., 2018). The application of experiential marketing appropriately can create experiential value, which then has a positive impact on repurchase intention, because one indicator of a company's success is determined by the continual repurchase of consumers (Astari \& Pramudana, 2016). Research conducted by Yanti et al. (2019), experiential marketing has a positive and significant effect on repurchase intentions.

In addition to making digital payments, the use of technology is also to search for information via the internet, namely with social media. The emergence of social media has changed the way marketing communication is carried out (Lagrosen \& Grundén, 2014). Marketing strategy through the internet network, namely social media, is increasingly important now (Ismail, 2017). The use of social media as a marketing strategy is useful for promotion practices in the industry and potentially in the future (Pan et al., 2014). Marketing using social media can increase product sales without place or time restrictions. Research conducted by Kristiani \& Dharmayanti (2017), shows that there is a significant influence of social media marketing on repeat purchases. With the high number of mobile payment service providers, companies must maintain and improve security systems. Community and customer trust in online payments greatly contribute to purchasing decisions (Cao et al., 2018). Product brands that consumers use, can give rise to experiences that have an impact on purchasing decisions. The level of trust in the brand of a product can result in consumer buying interest that is carried out repeatedly will be even greater. Consumer trust is the beginning of brand loyalty (Kartajaya, 2004). Further disclosed (Saleem et al., 2017); (Dharmayana \& Rahanatha, 2017), that brand trust has a positive effect on customer repurchase intentions. This study aims to explain and test how the effect of experiential marketing, social media, brand trust on repurchase intention is carried out partially on OVO applications in Denpasar.

\section{Literature review}

\section{Experiential marketing}

Experiential marketing is a form of marketing that is packaged in a variety of activities and provides experiences that can be inherent in the hearts of consumers (Candra, 2008). Experiential marketing is the process of identifying and satisfying consumer needs and lucrative aspirations, involving consumers through two-way communication, which carries brand personality characteristics and adds values to the target audience or customers (Smilansky, 2009; Heitzler et al., 2008; Sheu et al., 2009).

\section{Social media marketing}

Social media marketing is a process that encourages individuals to communicate product promotions through websites, through online social channels, by utilizing a much larger community than through traditional advertising channels (Weinberg, 2009). Forms of online advertising that use the cultural context of social communities include social networks, virtual worlds, social news sites, and various social opinion sites, to achieve the desired communication goals (Tuten, 2008; Erdoğmuş \& Cicek, 2012; Dahnil et al., 2014; Stephen, 2016; De Vries et al., 2012). Furthermore, 
consumer involvement in marketing actions through social media and references for other consumers involves local wisdom, and the occurrence of economic sharing (Subawa \& Widhiasthini, 2020).

\section{Brand trust}

Brand trust is a guideline for consumers to make purchases. Consumer trust in brands can reduce uncertainty, and assume what is chosen is the best and hopes to meet expectations (Tanojohardjo et al., 2014). Afzal et al. (2010), expressed that customer trust in the brand of a product can be interpreted as the customer's desire to determine and rely on a brand with all the risks faced. That is, expectations of the brand will cause positive things (Lassoued \& Hobbs, 2015; Eggers et al., 2013; Azize et al., 2012; Habibi et al., 2014).

\section{Repurchase intention}

Repurchase Intention will appeal to consumers because consumers have made previously and repeated purchases. Consumers who have the intention to make a repurchase will show their desire in the future (Tjiptono, 2004). That is, repurchase intention depends on consumer ratings obtained from transactions made in the past (Hellier et al., 2003). Purchasing interest is also influenced by changes in people's behavior, consumers, at present, more oriented to instant behavior, and hedonic tendencies (Subawa et al., 2020).

\section{Framework}

\section{The effect of experiential marketing on repurchase intention}

Experiential marketing is the process of identifying and satisfying the needs and aspirations of profitable consumers, as well as involving them in communication, as part of experiences that reflect brand characteristics and provide product values according to the target and target audience (Smilansky, 2009). The results of research and other researchers' statements, by Rahayu et al. (2016); Qori (2016); Andrianto (2017); shows that experiential marketing has a positive and significant effect on repurchase intention.

H1: Experiential marketing has a positive and significant effect on Repurchase Intention.

\section{Effect of social media marketing on repurchase intention}

Social media marketing is one form of marketing carried out through social media, to inform products, services, brands by utilizing customers as users of social media. This process, encourages individuals, sellers, marketers and other mentions, to promote their products through websites, through online social media channels and to carry out communication processes by utilizing large communities that have a major impact on repurchase interests (Weinberg, 2009). Furthermore, the results of research by Savitri et al. (2016), and Almas (2018), show that social media marketing has a positive and significant effect on repurchase intention. So a hypothesis can be made as follows.

H2: Social media marketing has a positive and significant effect on repurchase intention.

\section{The influence of brand trust on repurchase intention}

Trust in the brand of a product by consumers, can reduce all risks and uncertainties. The existence of trust in the brand, consumers will feel that the product they choose is the best brand and has fulfilled its expectations (Tanojohardjo et al., 2014). The results of research conducted by Fariz (2018) and Fang et al. (2011), show that brand trust has a positive and significant effect on repurchase intention so that hypotheses can be made and tested as follows.

H3: Brand trust has a positive and significant effect on repurchase intention.

Subawa, N. S., Widhiasthini, N. W., \& Suastika, N. P. M. W. S. (2020). The effect of experiential marketing, social media marketing, and brand trust on repurchase intention in Ovo applications. International Research Journal of Management, IT and Social Sciences, 7(3), 11-21. https://doi.org/10.21744/irjmis.v7n3.881 


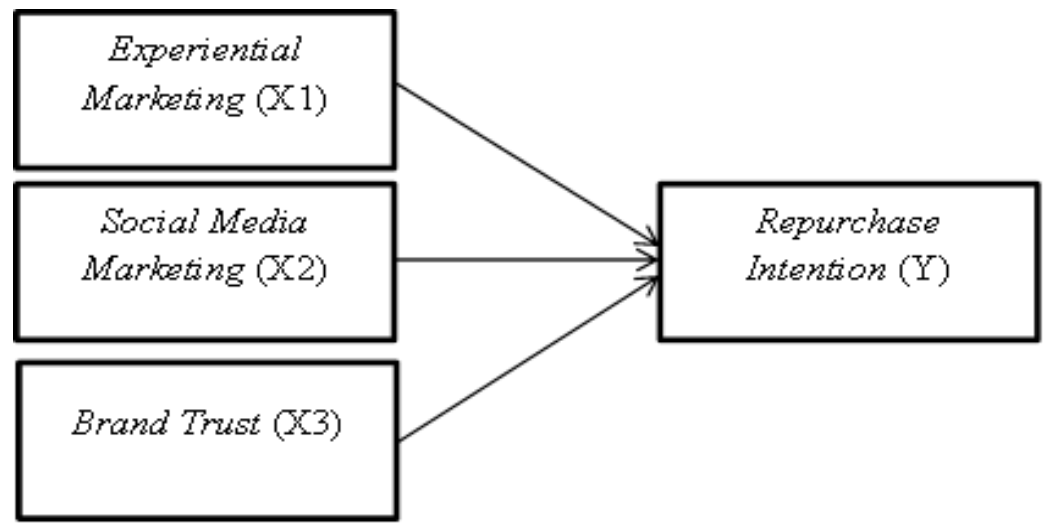

Figure 1. Framework

\section{Materials and Methods}

The research location is in the city of Denpasar, as the center of government, business and economic center in Bali. The population in this study are OVO application users in Denpasar City. The sampling technique used in this study is non-probability sampling, namely purposive sampling. Selected respondents have criteria, namely residing in the city of Denpasar, have or have used the OVO application, at least once and the respondent has a social media account. The determination of the number of samples in this study is 5-10 times the number of indicators of all variables. This study has 16 indicators as indicators. So the number of samples taken is a maximum of 10 times the number of indicators. This study used 160 samples, collecting data through questionnaires, with Likert scale items. The instrument was tested, through tests of validity and reliability. Data analysis techniques were carried out, namely through the classical assumption test, linear regression analysis, t-test, and the coefficient of determination using the SPSS for windows application.

\section{Results and Discussions}

In this study, the analysis was carried out using a statistical data processing program, namely SPSS. The data collected is then processed, analyzed and can be described as follows.

Validity and reliability test

Table 1

Validity test

\begin{tabular}{lllll}
\hline No & Variable & $\begin{array}{l}\text { Question } \\
\text { items }\end{array}$ & $\begin{array}{l}\text { Correlation } \\
\text { coefficient }\end{array}$ & Information \\
\hline 1 & Experential & X1.1 & 0,901 & Valid \\
& Marketing & X1.2 & 0,844 & Valid \\
& & X1.3 & 0,901 & Valid \\
& & X1.4 & 0,873 & Valid \\
\multirow{2}{*}{2} & Social & X1.5 & 0,878 & Valid \\
& Media & X2.1 & 0,817 & Valid \\
& Marketing & X2.3 & 0,857 & Valid \\
& & X2.4 & 0,904 & Valid \\
\multirow{2}{*}{3} & \multirow{2}{*}{ Brand Trust } & X2.5 & 0,733 & Valid \\
& & X3.1 & 0,897 & Valid \\
\hline
\end{tabular}




\begin{tabular}{lllll}
\hline \hline & & X3.3 & 0,933 & Valid \\
4 & X3.4 & 0,944 & Valid \\
4 & Repurchase & Y.1 & 0,658 & Valid \\
& Intention & Y.2 & 0,933 & Valid \\
& & Y.3 & 0,932 & Valid \\
& & Y.4 & 0,899 & Valid \\
\hline
\end{tabular}

Source: Primary Data Processed, 2019.

Table 2

Reliability test

\begin{tabular}{llll}
\hline No & Variable & Cronbach's Alpha & Information \\
\hline 1 & Experential Marketing & 0,922 & Reliable \\
2 & Social Media Marketing & 0,885 & Reliable \\
3 & Brand Truts & 0,934 & Reliable \\
4 & Repurchase Intention & 0,882 & Reliable \\
\hline
\end{tabular}

Source: Primary data processed, 2019.

In table 1, the results are obtained that all the items in experiential marketing, social media marketing, brand trust, and repurchase intention research variables are valid. All items on the instrument can be said to be valid because the results of all correlation coefficients are greater than 0.30 . Therefore, all statement items are said to be valid and appropriate.

In Table 2, it can be explained that all variables in the study, namely experiential marketing, social media marketing, brand trust, and repurchase intention are declared reliable. All variables to be tested can be said to be reliable because they have a Cronbach's alpha value above 0.6. Thus, all variables can be declared reliable and can be further analyzed.

Classic assumption test

Table 3

Normality test

\begin{tabular}{llr}
\hline \multicolumn{2}{c}{ One-Sample Kolmogorov-Smirnov Test } \\
\hline & & $\begin{array}{c}\text { Unstandardized } \\
\text { Residual }\end{array}$ \\
\hline $\mathrm{N}$ Normal Parameters & & 160 \\
& Mean & .0000000 \\
Most Extreme Differences & Std. Deviation & Absolute \\
& Positive & .065 \\
& Negative & .065 \\
Test Statistic & & -.065 \\
Asymp. Sig. (2-tailed) & .065 \\
a. Test distribution is Normal. & $.092^{\text {c }}$ \\
b. Calculated from data. & \\
c. Lilliefors Significance Correction. & \\
\hline
\end{tabular}

Source: Primary Data Processed, 2019

Subawa, N. S., Widhiasthini, N. W., \& Suastika, N. P. M. W. S. (2020). The effect of experiential marketing, social media marketing, and brand trust on repurchase intention in Ovo applications. International Research Journal of Management, IT and Social Sciences, 7(3), 11-21. https://doi.org/10.21744/irjmis.v7n3.881 
Table 4

Heteroscedasticity test

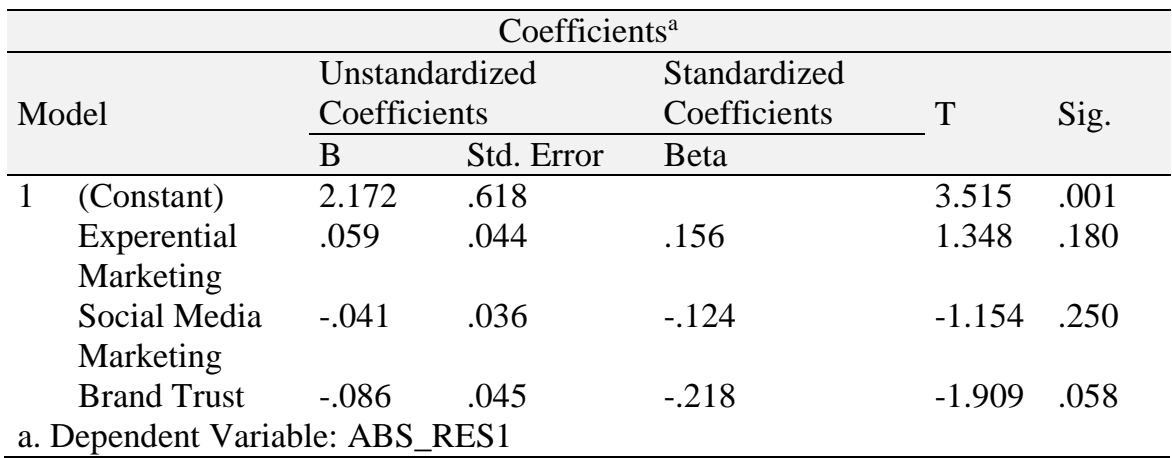

Source: Primary Data processed, 2019

Table 5

Multicollinearity test

\begin{tabular}{llcc}
\hline \multicolumn{4}{c}{ Coefficients $^{\mathrm{a}}$} \\
\hline \multirow{2}{*}{ Model } & & \multicolumn{2}{c}{ Collinearity Statistics } \\
\cline { 3 - 4 } & & Tolerance & VIF \\
\hline 1 & Experential Marketing & .454 & 2.202 \\
& Social Media Marketing & .532 & 1.879 \\
& Brand Trust & .467 & 2.141
\end{tabular}

a. Dependent Variable: Repurchase Intention

Source: Data Processed, 2019

Based on Table 3, it can be explained that the Kolmogorov Smirnov (K-S) value is 0.065 and the Asymp, Sig, (2tailed) value is 0.092 . The results of the data processing indicate that the data are normally distributed because the value of Asymp, Sig, (2-tailed) is greater than the alpha value of 0.05.

Likewise, in Table 4 it can be explained that the significance value of the experiential marketing variable is 0.180 ; significant value on social media marketing variables of 0.250 ; and significant value on the brand trust variable of 0.058 . From these results, all variables have a significance value greater than 0.05 , which means there is no heteroskedasticity.

Based on Table 5 it can be explained that the tolerance value of the experiential marketing variable is 0.454 ; social media marketing 0,532; and brand trust 0,467 and VIF value from experiential marketing variable 2,202; social media marketing 1,879; and brand trust 2,141. It can be concluded that the results show that the torance value of each variable is greater than 0.10 and the VIF value is smaller than 10 , which means that there is no multicollinearity.

Linear regression test

Table 6

Linear regression test

\begin{tabular}{|c|c|c|c|c|c|c|}
\hline \multicolumn{7}{|c|}{ Coefficients $^{\mathrm{a}}$} \\
\hline & & \multicolumn{2}{|c|}{$\begin{array}{c}\text { Unstandardized } \\
\text { Coefficients }\end{array}$} & $\begin{array}{c}\text { Standardized } \\
\text { Coefficients }\end{array}$ & \multirow[b]{2}{*}{$\mathrm{T}$} & \multirow[b]{2}{*}{ Sig. } \\
\hline \multicolumn{2}{|c|}{ Model } & B & Std. Error & Beta & & \\
\hline \multirow[t]{4}{*}{1} & (Constant) & 2.124 & .944 & & 2.251 & .026 \\
\hline & Experential Marketing & .186 & .067 & .209 & 2.781 & .006 \\
\hline & Social Media Marketing & .398 & .055 & .506 & 7.294 & .000 \\
\hline & Brand Trust & .143 & .069 & .155 & 2.089 & .038 \\
\hline $\mathrm{R}$ & & 0,775 & & & & \\
\hline
\end{tabular}




\begin{tabular}{ll}
\hline R Square & 0,600 \\
Adjusted $R$ Square & 0,593 \\
F hitung & 78,069 \\
Sig. & 0,000 \\
\hline
\end{tabular}

Source: Data Processed, 2019

Referring to the results of the regression analysis presented in Table 6, testing the first, second and third hypotheses, partially, the regression equation is obtained as follows.

$$
\mathrm{Y}=2,124+0,186 \mathrm{X} 1+0,398 \mathrm{X} 2+0,143 \mathrm{X} 3+\mathrm{e}
$$

The equation can be explained:

1) The regression equation, a constant value of 2.124; this means that if there is no change in the variables $X 1$ (experiential marketing), X2 (social media marketing), X3 (brand trust) that affect the repurchase intention has a value of 2,124 .

2) Variable $X 1$ (experiential marketing) is a variable that is thought to influence repurchase intention. Based on the analysis results obtained the significance value of experiential marketing variables on repurchase intention of 0.006 with a regression coefficient of 0.186 is positive. That is, the value of 0.006 is less than $0.05(0.006<0.05)$. Then the first hypothesis tested, shows that experiential marketing has a positive and significant effect on repurchase intention. So, the hypothesis can be accepted (H1 accepted). The effect is 0.186 , which means that if experiential marketing has increased by 1 unit, the repurchase intention will increase by 0.186 assuming other variables are considered constant.

3) Variable $X 2$ (social media marketing) is a variable that is thought to influence repurchase intention. Based on the results of the analysis obtained a significance value of social media marketing variables on repurchase intention of 0,000 with a regression coefficient of 0.398 and a positive value. That is, a value of 0,000 is less than $0.05(0,000$ $<0.05$ ), then the second hypothesis stating that social media marketing has a positive and significant effect on repurchase intention is declared true and acceptable ( $\mathrm{H} 2$ is accepted). The effect is 0.398 , meaning that if social media marketing has increased by 1 unit, the repurchase intention will increase by 0.398 assuming other variables are considered constant.

4) Variable $X 3$ (brand trust) is a variable that is thought to influence repurchase intention. Based on the results of the analysis, the significance value of the brand trust variable towards repurchase intention is 0.038 ; Regression coefficient of 0.143 is positive, and a value of 0.038 is less than $0.05(0.038<0.05)$. Then the hypothesis proposed stating that brand trust has a positive and significant effect on repurchase intention can be accepted (H3 accepted). The effect is 0.143 , meaning that if brand trust has increased by 1 unit, the repurchase intention will increase by 0.143 ; assuming other variables are considered constant.

\section{Determination coefficient test}

Table 7

Determination coefficient test

\begin{tabular}{lcccc}
\hline \multicolumn{4}{c}{ Model Summary } \\
\hline Model & $\mathrm{R}$ & $\mathrm{R}$ Square & $\begin{array}{c}\text { Adjusted R } \\
\text { Square }\end{array}$ & $\begin{array}{c}\text { Std. Error of the } \\
\text { Estimate }\end{array}$ \\
\hline 1 & $.775^{\mathrm{a}}$ & .600 & .593 & 1.791 \\
\hline a. Predictors: (Constant), Brand Trust, Social Media Marketing, \\
Experential Marketing \\
b. Dependent Variable: Repurchase Intention \\
Source: Primary Data Processed, 2019
\end{tabular}

Subawa, N. S., Widhiasthini, N. W., \& Suastika, N. P. M. W. S. (2020). The effect of experiential marketing, social media marketing, and brand trust on repurchase intention in Ovo applications. International Research Journal of Management, IT and Social Sciences, 7(3), 11-21. https://doi.org/10.21744/irjmis.v7n3.881 
Referring to Table 7, the magnitude of the effect of independent variables on the dependent variable shown by the total determination value (Adjusted R Square) of 0.593 which means that $59.3 \%$ of the repurchase intention variable (Y) is influenced by experiential marketing variables (X1), social media marketing (X2), and brand trust (X3), while the remaining $40.7 \%$ that repurchase intention is influenced by other variables that are unknown and not tested in this study.

\section{Discussion}

\section{The Effect of Experiential Marketing on Repurchase Intention on OVO Applications in Denpasar City}

Based on the analysis results obtained the significance value of experiential marketing variables on repurchase intention of 0.006 with a regression coefficient of 0.186 which is positive, the value of 0.006 is less than $0.05(0.006$ $<0.05$ ). This means that experiential marketing has a positive and significant effect on repurchase intention on OVO applications in Denpasar. Experiential marketing has a positive and significant effect on repurchase intention. This means that each increase in experiential marketing will increase repurchase intention. Vice versa, every decrease in experiential marketing will decrease repurchase intention. Experiential marketing is a way to make customers create experiences for a brand. Experiential marketing is the process of identifying and satisfying consumer needs and beneficial aspirations, engaging consumers through two-way communication that brings brand personality to life and adds value to the target audience (Smilansky, 2009).

This was confirmed by previous research conducted by Rahayu et al. (2016); Qori (2016); Andrianto (2017), where the results of the study showed that Experiential Marketing had a positive and significant effect on Repurchase Intention.

2. Effect of Social Media Marketing on Repurchase Intention on OVO Applications in Denpasar City

Based on the results of the analysis, the significance value of the social media marketing variable was obtained against the repurchase intention of 0,000 with a regression coefficient of 0.398 with a positive value, a value of 0,000 less than $0.05(0,000<0.05)$. This result means that social media marketing has a positive and significant effect on repurchase intention on OVO applications in Denpasar.

Social media marketing has a positive and significant effect on repurchase intention. Every increase in social media marketing, there will be an increase in repurchase intention. The opposite also happens that for every decline in social media marketing, there will be a decrease in repurchase intention.

The results of this study also support the results of previous studies conducted by Savitri et al. (2016); Almas (2018) and Fang et al. (2011), which show that social media marketing has a positive and significant effect on Repurchase Intention.

\section{Effect of Brand Trust on Repurchase Intention on OVO Applications in Denpasar City}

Referring to the results of the analysis, the significance value of the brand trust variable towards repurchase intention is 0.038 with a regression coefficient value of 0.143 which is positive, a value of 0.038 less than 0.05 $(0.038<0.05)$. This result means that brand trust has a positive and significant effect on repurchase intention on OVO applications in Denpasar.

Brand trust has a positive and significant effect on repurchase intention. Every increase in the brand trust will increase repurchase intention, and vice versa, every decrease in the brand trust will decrease repurchase intention. The results of previous studies conducted by Fariz (2018); Subawa (2016) and Fang et al. (2011), reinforce the results of this study, that Brand Trust has a positive and significant effect on Repurchase Intention.

\section{Conclusion}

Based on this discussion, it can be concluded that experiential marketing has a positive and significant effect on repurchase intention. Social media marketing has a positive and significant effect on repurchase intention. Brand trust has a positive and significant effect on repurchase intention.

Further research can be carried out by other researchers, related to other variables not tested and examined in this study, which is equal to $40.7 \%$ determined by other variables. For example, endorsement, security and application 
consistency variables are carried out in Denpasar or other major cities. Consumer considerations in repurchase intention extended not only to the OVO application but can be investigated in other consumer service products.

Conflict of interest statement

The authors declared that they have no competing interests.

Statement of authorship

The authors have a responsibility for the conception and design of the study. The authors have approved the final article.

Acknowledgments

We are grateful to two anonymous reviewers for their valuable comments on the earlier version of this paper.

Subawa, N. S., Widhiasthini, N. W., \& Suastika, N. P. M. W. S. (2020). The effect of experiential marketing, social media marketing, and brand trust on repurchase intention in Ovo applications. International Research Journal of Management, IT and Social Sciences, 7(3), 11-21. https://doi.org/10.21744/irjmis.v7n3.881 


\section{References}

Afzal, H., Khan, M. A., ur Rehman, K., Ali, I., \& Wajahat, S. (2010). Consumer's trust in the brand: Can it be built through brand reputation, brand competence and brand predictability. International Business Research, 3(1), 43.

Almas, C. (2018). Pengaruh Relationship Marketing, Store Atmosphere dan Social Media Marketing Terhadap Customer Trust Dan Repurchase Intention Pelanggan (Studi Kasus pada Coffee Shop di Kota Bogor). Institut Pertanian Bogor, Jawa Barat

Andrianto, G.D. (2017). Pengaruh Experiential Marketing Terhadap Repurchase Intention Melalui Customer Satisfaction Sebagai Intervening Variabel (Studi Pada The Bagong Adventure Museum Tubuh), Thesis, Universitas Brawijaya, Malang

Astari, W. F., \& Pramudana, K. A. S. (2016). Peran experiential value dalam memediasi pengaruh experiential marketing terhadap repurchase intention. Matrik: Jurnal Manajemen, Strategi Bisnis dan Kewirausahaan.

Azize, Ş., Cemal, Z., \& Hakan, K. (2012). Does brand communication increase brand trust? The empirical research on global mobile phone brands. Procedia-Social and Behavioral Sciences, 58, 1361-1369. https://doi.org/10.1016/j.sbspro.2012.09.1120

Cao, X., Yu, L., Liu, Z., Gong, M., \& Adeel, L. (2018). Understanding mobile payment users' continuance intention: a trust transfer perspective. Internet Research. https://doi.org/10.1108/IntR-11-2016-0359

Chandra, H. (2008). Marketing untuk orang awam. Palembang: Maxikom.

Dahnil, M. I., Marzuki, K. M., Langgat, J., \& Fabeil, N. F. (2014). Factors influencing SMEs adoption of social media marketing. Procedia-social and behavioral sciences, 148, 119-126. https://doi.org/10.1016/j.sbspro.2014.07.025

De Vries, L., Gensler, S., \& Leeflang, P. S. (2012). Popularity of brand posts on brand fan pages: An investigation of the effects of social media marketing. Journal of interactive marketing, 26(2), 83-91. https://doi.org/10.1016/j.intmar.2012.01.003

Dharmayana, I. M. A., \& Rahanatha, G. B. (2017). Pengaruh Brand Equity, Brand Trust, Brand Preference, dan Kepuasan Konsumen Terhadap Niat Membeli Kembali. E-Jurnal Manajemen, 6(4), 2018-2046.

Dinh, V. S., Nguyen, H. V., \& Nguyen, T. N. (2018). Cash or cashless? Promoting consumers' adoption of mobile payments in an emerging economy. Strateg Dir, 34(1), 1-4.

Eggers, F., O'Dwyer, M., Kraus, S., Vallaster, C., \& Güldenberg, S. (2013). The impact of brand authenticity on brand trust and SME growth: A CEO perspective. Journal of World Business, 48(3), 340-348. https://doi.org/10.1016/j.jwb.2012.07.018

Erdoğmuş, İ. E., \& Cicek, M. (2012). The impact of social media marketing on brand loyalty. Procedia-Social and Behavioral Sciences, 58, 1353-1360. https://doi.org/10.1016/j.sbspro.2012.09.1119

Fang, Y. H., Chiu, C. M., \& Wang, E. T. (2011). Understanding customers' satisfaction and repurchase intentions. Internet Research. https://doi.org/10.1108/10662241111158335

Fariz, A. (2018). Peningkatan Brand Preference Dan Brand Trust Melalui Brand Identity Terhadap Repurchase Intention (Studi pada Mahasiswa Pengguna Sepeda Motor Sport Merek Honda di Unissula Semarang) (Doctoral dissertation, Fakultas Ekonomi UNISSULA).

Febrini, I. Y., Widowati, R., \& Anwar, M. (2019). Pengaruh Experiential Marketing Terhadap Kepuasan Konsumen Dan Minat Beli Ulang Di Warung Kopi Klotok, Kaliurang, Yogyakarta. Jurnal Manajemen Bisnis, 10(1), 35-54. https://doi.org/10.18196/mb.10167

Habibi, M. R., Laroche, M., \& Richard, M. O. (2014). The roles of brand community and community engagement in building brand trust on social media. Computers in human behavior, 37, 152-161. https://doi.org/10.1016/j.chb.2014.04.016

Heitzler, C. D., Asbury, L. D., \& Kusner, S. L. (2008). Bringing "play" to life: the use of experiential marketing in the VERB ${ }^{\mathrm{TM}}$ campaign. American journal of preventive medicine, 34(6), S188-S193. https://doi.org/10.1016/j.amepre.2008.03.009

Hellier, P. K., Geursen, G. M., Carr, R. A., \& Rickard, J. A. (2003). Customer repurchase intention. European journal of marketing. https://doi.org/10.1108/03090560310495456

Ismail, A. R. (2017). The influence of perceived social media marketing activities on brand loyalty. Asia Pacific Journal of Marketing and Logistics. https://doi.org/10.1108/APJML-10-2015-0154

Kartajaya, H. (2004). Seri 9 Elemen Marketing, Hermawan Kertajaya on Brand. Bandung: PT. Mizan Pustaka.

Kristiani, P., \& Dharmayanti, D. (2017). Pengaruh Social Media Marketing terhadap Repeat Purchase dengan Variabel Intervening Perceived Service Quality dan Brand Image pada Industri Fast-Food Restaurant di Surabaya. Petra Business and Management Review, 3(1). 
Lagrosen, S. O., \& Grundén, K. (2014). Social media marketing in the wellness industry. The TQM Journal, 26(3), 253-260. https://doi.org/10.1108/TQM-12-2013-0129

Lassoued, R., \& Hobbs, J. E. (2015). Consumer confidence in credence attributes: The role of brand trust. Food Policy, 52, 99-107. https://doi.org/10.1016/j.foodpol.2014.12.003

Mawarrini, R. I. (2017). Identifikasi Pembayaran Bergerak (Mobile Payment) yang Mengganggu (Disruptive) di Indonesia. Perisai: Islamic Banking and Finance Journal, 1(3), 215-226. https://doi.org/10.21070/perisai.v1i3.1179

Nejad, M. G., Apanasevic, T., Markendahl, J., \& Arvidsson, N. (2016). Stakeholders' expectations of mobile payment in retail: lessons from Sweden. International Journal of Bank Marketing.

Nugroho, P., Winarno, W. W., \& Hartanto, R. (2017). Faktor-faktor yang mempengaruhi niat menggunakan mobile payment dengan pendekatan extended the unified theory of acceptance and use of technology. CITEE Dep. Tek. Elektro dan Teknol. Informasi, FT UGM, 226-233.

Pan, J., Vorvoreanu, M., \& Zhou, Z. (2014). Social media adoption in disaster restoration industry. Construction Innovation. https://doi.org/10.1108/CI-03-2013-0014

PriceWaterhouseCoopers, L. L. P. (2019). Guide to key performance indicators. Accessed online June.

Qori, R. (2016). Pengaruh experiential marketing terhadap repurchase intention (Studi Pada Pelanggan Reguler PT. Combina cargo) (Doctoral dissertation, Universitas Andalas).

Rahayu, D., Kumadji, S., \& Kusumawati, A. (2016). Experiental Marketing Dan Pengaruhnya Terhadap Kepuasan Pelanggan Dan Minat Pembelian Ulang (Repurchase Intention)(Survei Padapelanggan Warung Coto Abdullah Daeng Sirua, Kota Makassar). Jurnal Administrasi Bisnis, 35(2), 197-203.

Saleem, M. A., Zahra, S., \& Yaseen, A. (2017). Impact of service quality and trust on repurchase intentions-the case of Pakistan airline industry. Asia Pacific Journal of Marketing and Logistics. https://doi.org/10.1108/APJML-102016-0192

Savitri, E.K., Zahara, Z., dan Ponirin, (2016). Pengaruh Promosi Melalui Media Sosial Terhadap Repurchase Intention Melalui Electronic Word of Mouth Pada RM Radja Penyet Mas Fais di Kota Palu Jurusan Manajemen, Universitas Tadulako, Palu

Sheu, J. J., Su, Y. H., \& Chu, K. T. (2009). Segmenting online game customers-The perspective of experiential marketing. Expert systems with applications, 36(4), 8487-8495. https://doi.org/10.1016/j.eswa.2008.10.039

Smilansky, S. (2009). Experiential Marketing a practical guide to interactive Brand.

Stephen, A. T. (2016). The role of digital and social media marketing in consumer behavior. Current Opinion in Psychology, 10, 17-21. https://doi.org/10.1016/j.copsyc.2015.10.016

SUBAWA, N. S. (2016). Prestige Pricing Strategy as A Symbol of Social Class on Perfume Products. Jurnal Bisnis dan Manajemen, 17(1), 13-21. http://dx.doi.org/10.24198/jbm.v17i1.2

Subawa, N. S., Widhiasthini, N. W., Pika, P. A. T. P., \& Suryawati, P. I. (2020). Hedonism on the behavior of consumer society as a global cultural transformation. International research journal of management, IT and social sciences, 7(2), 59-70. https://doi.org/10.21744/irjmis.v7n2.878

Subawa, N.S. \& Widhiasthini, N.W. (2020). Hegemony practice of consumers in disruption era. International Journal of Innovation, Creativity and Change, 11 (3), 357-375.

Tanojohardjo, G. A. (2014). Analisa Hedonic Value dan Utilitarian Value terhadap Brand Trust dengan Brand Satisfaction sebagai Variabel Intervening pada Produk Pewarnaan LOréal Professionnel. Jurnal Strategi Pemasaran, 2(1), 1-11.

Tjiptono, F., (2004). Pemasaran Jasa. Bayumedia Publishing. Malang

Tuten, T. L. (2008). Advertising 2.0: social media marketing in a web 2.0 world: social media marketing in a web 2.0 world. ABC-CLIO.

Weinberg, T. (2009). The new community rules: Marketing on the social web. https://doi.org/10.1108/dlo.2011.08125cae.002

Subawa, N. S., Widhiasthini, N. W., \& Suastika, N. P. M. W. S. (2020). The effect of experiential marketing, social media marketing, and brand trust on repurchase intention in Ovo applications. International Research Journal of Management, IT and Social Sciences, 7(3), 11-21. https://doi.org/10.21744/irjmis.v7n3.881 